\title{
Of all foods bread is the most noble: Carl von Linné (Carl Linneaus) on bread'
}

\author{
Leena Räsänen
}

Division of Nutrition, Department of Applied Chemistry and Microbiology, University of Helsinki, Finland

\begin{abstract}
Carl von Linné was interested in dietetics, which in his time covered all aspects of a healthy life. As a utilitarian he understood the importance of private economy and paid attention to bread in many of his publications. Two texts, Ceres noverca arctoum and De pane diaetetico, were wholly devoted to bread and bread-making. Linné classified different types of bread, and described their nutritional value and healthrelated aspects, as well as milling, baking and storing, in detail. While discussing the food habits of social classes Linné accepted as a fact that the peasants and the poor should eat less tasty bread than the rich. The less palatable bread had, however, many nutritional and health advantages. Linné paid much attention to substitutes for grain to be used in times of famine, an important topic in eighteenth century Sweden. He regarded flour made of pine bark or water arum roots as excellent famine food, was enthusiastic about the new plant, maize, but considered potato only as a poor substitute for grain. Linné and his followers praised bread not only as the core component of diet, but also for its versatile role both in health and in disease.
\end{abstract}

Keywords: baking; eighteenth century; food history; health; nutrition; Sweden

\section{Introduction}

Of all foods bread is in truth the most noble. It is a food that is so necessary that we usually describe a true pauper with the words "he has not even a crumb of bread". It is served on the tables of both the rich and the poor, is beneficial in all diseases and suitable for all temperaments and it imparts a pleasant taste to food that is of itself tasteless. Therefore, since bread is so widespread and strengthens us and pleases our taste, I beg you distinguished reader, to not feel disturbed by paying attention to a dietetic investigation of bread.

Carl von Linné wrote these sentences 250 years ago for the introduction of an academic thesis, a dissertation, entitled De pane diaetetico (1). Actually, Carolus Linnaeus did not adopt the name von Linné until 4 years later, in 1761, when he was ennobled (2). In the following, however, the name Linné, by which he is generally known nowadays, will be used even when referring to his earlier career.

Cereal foods have been used in southern Scandinavia since the onset of the neolithic period about 6000 years ago (3). In the more northern areas and

\footnotetext{
${ }^{1}$ Plenary presentation at the conference "Cultina mutata - the changing kitchen, Uppsala Food and Nutrition Centre, 3-5 September 2007.
}

in Finland, the cultivation of grain did not start until about 2000 years later. Wheat and barley were the first grains to be cultivated, but in the eighteenth century the predominant grains in Sweden and Finland were barley and rye, wheat having only a minor role $(4,5)$. Until potatoes revolutionized the diet in the nineteenth century (6) cereal foods different types of bread, porridge and gruel - were the most important items of the daily fare of the common people and provided the greatest share of their energy intake (7).

Carl von Linné was a utilitarian who promoted science for practical use and understood the importance of a private economy for the wellbeing of the nation. In several of his publications he paid attention to bread and bread-making.

\section{Notes and books on bread}

When the 27-year-old Linné undertook his first journey abroad, his destination was Holland, where he received a doctoral degree in medicine in 1735 (2). With him he had taken notes and drafts for 30 papers he was to publish years later. Among them was a manuscript entitled Ceres noverca arctoum (The stepmotherly Ceres of the North), obviously intended as a draft for a more extensive publication (8). It was to be a description of all different types 
of bread, as well as of substitutes for grain. The text was never finished, but Linné used the material included in these notes subsequently in several publications. Linné was a professor of medicine in Uppsala when he treated the subject of famine bread in certain dissertations, for example, in Flora oeconomica in 1748 and in Plantae esculentae patriae in $1752(9,10)$. The list of plants suitable for bread-making grew longer in each successive publication.

Linné's most extensive publication on bread was a dissertation entitled De pane diaetetico (On bread as a food component) (1). In accordance with the custom, De pane diaetetico was written and supervised by Linné himself and defended by his student Isaac Svensson in 1757. This text started with a systematic classification of the various types of bread used in Sweden. Some foreign, even exotic, breads as well as examples of breads used in antiquity were also mentioned. The other chapters described the digestion and the health-related aspects of bread, as well as milling, baking and storing in detail (10).

Linné's academic duties in Uppsala included lecturing not only on botany and materia medica but also on a subject in which he had become very interested, dietetics, which at that time was understood to cover all aspects of a natural and healthy life (2). His lectures on bread, particularly foreign breads and famine breads, were published in the compilation of his own surviving lecture notes, entitled Lachesis naturalis quae tradit diaetam naturalem, and those of his students, Collegium diaeteticum (11).

In this review, the thoughts of Linné are described and discussed mainly on the basis of the two texts wholly devoted to bread, Ceres noverca arctoum (8) and De pane diaetetico (1).

\section{Ancient Romans and Dutch colleagues}

Linnés writings on bread reveal how widely read he was. His quotations from literature were more often references to the classical authors than to the fellow scientists of his own time. Hippocrates and Galen, the greatest medical authorities of antiquity, were diligently cited, but examples and comments were also taken from the texts of the naturalist Pliny and the poet Vergil, the philosopher Seneca and the satirist Juvenal, for example. Equally frequent quotations were merited only by the famous Dutch physician, chemist and botanist Herman Boerhaave, who Linné had met in Leiden in 1735. Boerhaave had been one of the first to recognize Linné's talents, and the two men eventually became good friends (2). Linné had also read the publications of Swedish authors, for example, Sven Lagerlöf's Wälmente tanckar on spannemåhls skiötsel, published in 1719, from which he loaned whole chapters (10).

\section{Types of bread}

Linné's own observations from his provincial tours had given ample material for the detailed and concrete descriptions of bread-making. Some of these descriptions might even have stemmed from childhood memories of the habits of the peasant folk in Stenbrohult (2). Linné was an accurate observer who always emphasized the importance of trusting his own experiences.

As a great systematist, Linné started both texts with a logical arrangement of the different types of

Table I. Different types and varieties of bread, presented by Carl von Linné in De pane diaetetico in 1757 (I)

\begin{tabular}{|c|c|}
\hline Category & Varieties of bread \\
\hline \multirow[t]{5}{*}{ I. Single types } & Wheat bread \\
\hline & Rye bread \\
\hline & Barley bread \\
\hline & Oat bread \\
\hline & Bran bread \\
\hline \multirow[t]{3}{*}{ II. Compound types } & Sweet bread \\
\hline & Saffron bread \\
\hline & Pumpernickel \\
\hline \multirow[t]{4}{*}{ III. According to preparation method } & Unsieved bread \\
\hline & Yeast bread \\
\hline & Sourdough bread \\
\hline & Unleavened bread \\
\hline \multirow[t]{8}{*}{ IV. According to shape } & Cakes \\
\hline & Buns \\
\hline & Loaves \\
\hline & Rusks \\
\hline & Twist biscuits \\
\hline & Succaria \\
\hline & Hardtack \\
\hline & Flatbread \\
\hline \multirow[t]{3}{*}{ V. States of bread } & Warm \\
\hline & Soft \\
\hline & Dry \\
\hline \multirow[t]{5}{*}{ VI. Faults in bread } & Collapsed \\
\hline & Rock hard \\
\hline & Burnt \\
\hline & Mouldy \\
\hline & Worm eaten \\
\hline
\end{tabular}


bread. In De pane diaetetico the classification was based on six criteria (Table 1). First, wheat, rye, barley, oat and bran bread were listed as single types of bread with short comments on their use and nutritional value. Secondly, Linné mentioned a few sweetened or spiced breads as compound types. The third criterion was the preparation method. The next criterion was more unusual, the shape of the bread. The fifth criterion was the state of the bread, whether warm directly from the oven, soft or dry. Finally, different faulty or spoiled breads were listed.

The earlier manuscript, Ceres noverca arctoum, started with a similar but somewhat less detailed classification. The composition and the shape of bread were used as criteria, but breads were also categorized as ordinary (ordinarii) and substitute breads (vicarii).

\section{Bread-baking and storing}

In De pane diaetetico Linné described the main phases of bread-making. The process began with the removal of foreign seeds and sand from grain, which was then dried. In the milling an important aspect was the choice of a suitable material for millstones. Since he had observed the ill effects of the use of sandy millstones in Norway, he considered the use of sandstone a grave error, which resulted in "sandy bread, stomach affliction common in certain parts of the country, and finally may cause a tragic death".

After milling, the flour would be separated from the bran with a sieve if a fine bread was desired. The dough was a mixture of hot water, flour and a little salt. Yeast or sourdough was added to start the fermentation, which took place overnight. The next day the mass was kneaded and formed into different shapes, thick buns or cakes, large loaves or thinner cakes. The breads were then baked in ovens, except for the twist biscuits, which were boiled in water.

The most common bread in the eighteenth century was of the thinner type, since it was intended to be dried and preserved throughout the year.

Since most of the bread consumed in Sweden in Linné's time was eaten dry, often months old, proper storage was important. Linné knew that mouldy bread was "as unhealthy as spoiled meat". He wrote, "All mould has bitter taste and disgusting and noxious smell.... Furthermore, mould has a septic, consuming and dissolving action." Therefore, bread should be stored in dry and cool rooms.
Another common cause of spoilage was larvae infestation, wherefore bread should be "placed into chests once baked so that worms could not lay their eggs in it".

\section{Regional differences in bread types}

Ethnological research has identified distinct regional differences in the traditional types of bread consumed in Sweden and Finland (4, 12). For centuries, ecological conditions have determined which grains could be successfully cultivated and which preparation methods were expedient for bread-making. In southern Sweden and eastern Finland the predominant bread type was eaten fresh and soft, whereas elsewhere bread was baked more seldom and eaten dry and hard. The flat barley bread, rieska, was typical in the northernmost part of the country.

Linné was familiar with the regional differences in bread types. He had observed that soft sourdough bread was used by farmers in southern Sweden, in Skåne, and he mentioned that bread fermented with yeast was consumed in the middle of the country, in Uppland and Småland, whereas in the northern provinces the most common type of bread was unleavened and "as thin as paper".

\section{Bread for the peasants and the aristocracy}

Noticeable changes took place in the population structure and social division in eighteenth century Sweden. The estate system was transforming into a class society (13). The strengthening middle class was striving for a more refined way of life than ever before and took a leading role in cultural development. Another great change, even more important socially, was the new and growing role of farmers in the struggle for self-supporting economy during the decades of war and in the frequent years of famine.

In many contexts Linné explained how people with different standing in society eat different types of bread. He wrote, "Wheat bread, the most excellent of all, is used only by high-class people", whereas "barley bread is used by our peasants" and "oat bread is common among the poor". He made a remark that "the upper classes use milk instead of water in the dough, as they wish to have a whiter and better bread, which thereby acquires a more pleasant taste". He compared his own knowledge on the food habits of Swedish society with those mentioned in classical literature. Thus, according to Linné, Juvenal wrote that "a soft and snow-white 
bread of the finest wheat is given to the master", while Galen condemned oat bread as suitable only for cattle, not for humans. Here Linné had to admit that it is, however, consumed in certain provinces in Sweden.

Linné was aware of and discussed the consequences of consuming less tasty and less satisfying bread, but he seems to have accepted as a fact that people belonging to different social classes should use different foods to satisfy their hunger. For example, he commented that "bran is more difficult to digest than flour, except for hard-labouring peasants and the likes, who are scarcely troubled by it". The necessity of having to eat filling but less palatable bread was inevitable, but could be even positive from the nutritional point of view. "In Östergötland they mix the grain with flour made from peas and in Scania with vetch, so that the bread may be more nutritious for the hard-working peasants, but at the same time it becomes less flavoursome, drier and less pleasing to the palate." And, "Soft bread is used mainly by the aristocracy and the rich, but it weakens the gums and teeth, which get too little exercise in chewing. However, the peasant folk who eat hard bread cakes generally have stronger teeth and firmer gums".

It is intriguing that Linné did not find it necessary to discuss the consumption or effect on health of other bakery products, such as the sweet cakes, tarts, pies and biscuits served by the fashionconscious upper class and the most prosperous bourgeois. Several cookery books with recipes for the fashionable pastry products were published in Sweden in the eighteenth century (14). The most famous of these, Hjelpreda i Hushållningen för Unga Fruentimmer by Kajsa Warg, published in 1755, included many recipes for sweet pastries (15). Linné mentioned only in passing that the addition of egg makes the bread moist and crumbly, and sugar and currants impart a good flavour.

The sweet and decorated pastries were usually consumed with wine or with the new exotic beverages, tea and coffee. It is probable that Linné regarded pastries as unnecessary luxuries, since expensive imported ingredients, sugar and spices, were indispensable in their preparation. He had even written a list of things that he considered superfluous, among them wines and spirits, tea and coffee, sugar, confections, desserts, raisins, cinnamon and nutmeg $(16,17)$. Linné admired the natural diet and way of life he had observed during his provincial tours, and compared them favourably to those of the French $(18,19)$.

\section{Nourishment from different types of bread}

When discussing the nutritional characteristics and value of breads, Linné evaluated their effect on digestion, on the production of digestive juices and on the motility of the intestines. Since antiquity, scholars, from Hippocrates and Aristotle to medieval Avicenna and the alchemical physician Paracelsus, had been preoccupied with the explanation of the digestive processes (20). Linné followed this tradition. He stated, "With regard to nourishment, there is a great difference between different types of bread". Linné considered wheat bread "the most excellent of all", whereas bran bread was the most difficult to digest and contained the least amount of nutrients. Linné was aware that rye bread was less constipating than breads made from other grains. $\mathrm{He}$ praised the virtues of dry rusks, which he regarded as the best type of bread owing to their capacity to absorb the most saliva in chewing and, thus, to stimulate digestion.

Fresh bread, particularly if eaten warm, had the opposite qualities of rusks. Linné emphasized that soft and fresh bread does not draw in as much saliva and thus remains undigested for a long time, "like a stone in the stomach". He strongly warned against eating warm bread with butter. While it was "considered as a delicacy, there was scarcely another food that was more damaging for the stomach and teeth, for they were loosen'd by it and fell out". By way of illustration he told an example reported by a doctor who lived in a town near Amsterdam. Most of the inhabitants of this town were bakers, who sold bread daily to the residents of Amsterdam and had the practice of attracting customers with oven-warm bread, sliced and spread with butter. According to Linné, this particular doctor was not surprised when most of the residents of this town "suffered from bad stomach, poor digestion, flatulence, hysterical afflictions and 600 other problems".

\section{Beneficial in all diseases}

When Linné wrote that bread is "suitable for all temperaments", he was referring to the concept of the four basic human temperaments formulated by Galen in the second century. In the eighteenth century the Hippocratic and Galenic doctrines of the nature of diseases and temperaments were still 
prevalent in medicine, even as they began to give way to progress in pathology and practical medicine (21). The theory was based on the principle that man and his food contain within themselves the same four elements. These - air, fire, water and earth - manifested in the human body in the form of four equivalent fluids or humours - blood, bile, phlegm and black bile. If men suffered from excess or insufficiency of certain of these elements, the imbalance, dyscrasia, changed their physical qualities accordingly towards too much hot or cold, dry or wet, and caused an illness. To restore the balance, it was necessary to eat foods with the counteracting qualities (22).

The balance principle of humoral pathology and Galen's classification of remedies as sweet, acidic, salty or bitter can be seen in Linné's medical thinking. For example, barley bread was less tasty than rye bread, but sweeter and more cooling. Linné considered oats more acid forming than barley, and rye, wheat and buckwheat each less acid forming in descending order. From this he inferred which type of bread should be used for each disease. For example, since oats provided the most acid, oat drinks served as cooling agents during fevers and when there was a threat of such. Food prepared from oats or sour bread was less suitable in hysteria, dropsy - the accumulation of water in the tissues and cold chills.

Linné gave some examples of how bread can cause, prevent or cure specific diseases. Referring to Galen, he stated that bread eaten raw inflates the intestines and gives stomach cramps. Therefore it must be properly fermented before baking. Those who had weak intestines or whose powers were depleted by disease were recommended "to eat rusks and to crush them thoroughly between the teeth". According to Linné, chewing the bread well greatly assisted the digestion. To illustrate this Linné gave this example: "Those who receive punishment of living on bread and water often lose their health. They develop dropsy and eventually die in a prolonged wasting disease, especially if they have been foolish enough to eat the bread dipped in the water. If, however, they had eaten the bread dry and had drunk the water thereafter they would have retained their health, and would thereafter even been much healthier." Linné referred to the instructions of his Dutch colleague Boerhaave, who prescribed for consumptive patients, those suffering from tuberculosis, "plentiful rusk bread which they should eat dry and thereafter take some Rhenish wine, so as to strengthen the fibres with the former, the nerves with the latter".

Linné mentioned spices and herbs not only as flavour-enhancing components of bread, but also as ingredients with a medicinal effect. He listed saffron, coriander, aniseed, cumin, fennel and black cumin as stomach strengthening; they also increased breast milk, drove out urine and reduced the problems of wind-causing foods. They should be used sparingly in bread, however, so that baking would not weaken or impede their narcotic power. Since ancient times, spices and herbs had been as important in medicine, as drugs and remedies, as they were in the seasoning of food (20). Herbs were grown for these purposes in kitchen gardens. In the second half of the eighteenth century, both locally grown and imported herbs and spices were an indispensable part of pharmacy.

\section{Bread not common in Sweden}

In both De pane diaetetico and in Ceres noverca arctoum Linné mentioned breads that were not consumed in Sweden but were common in other countries, some as far away as in India, Africa and America. Linné's main sources seem to have been Dutch publications, but he probably also relied on data collected by his students, the "apostles", who travelled overseas to investigate plants of distant lands $(2,23)$. Linné ranked utility before curiosity and instructed his students to bring home new crops and import substitutes (24).

Rice and maize were the most important foreign grains that Linné described. Rice, used in India both as bread and as porridge, was judged as good and satisfying food if eaten cold. When eaten warm, however, it was thought to be damaging to the nerves and particularly to the eyes, according to Linné's source Jacobus Bontius. In 1642, Bontius was the first western physician who supplied scientific documentation of the disease beriberi, much later recognized as thiamin deficiency (25).

In the eighteenth century maize was grown for food not only in the Americas, but also in southern European countries. Linné described maize bread as desiccating, constipating and gas forming, and thus suitable for labourers, such as porters, ships' crews and servants. Sorghum and millet were also mentioned, the former as grain used in Italy, the latter in France. 


\section{Bread with little or no grain}

Linné was not the first in Sweden to write about famine bread. Among his remaining papers in London there are copies from two official documents from 1696 concerning the crop failure in the northern parts of Sweden and the possibility of preparing flour from different roots, and an anonymous small paper which contained descriptions of 21 plants, the roots or leaves of which could be used for flour (10). These texts had obviously been studied by Linné with interest.

When writing about substitute breads, Linné formulated his aim as the following: "It will teach the poor peasant to bake bread with little or no grain in the circumstance of crop failure without destroying the body and health with unnatural foods, as often happens in the countryside in years of hardship" (10).

Linnés idea for a publication on bread substitutes probably originated during his early journeys to Lapland and Dalarna, where grain substitutes were a necessity even in good years. Actually, bark bread was eaten in northern Sweden until the late nineteenth century (4). In the poorest regions of eastern and north-eastern Finland it was still consumed in the 1920s (26).

Linné had the opportunity to make exact field notes on the use of, for example, pine bark and water arum roots in bread-making, which he described later in Iter lapponicum and Flora lapponica (8). Indeed, the question of substitutes to be used in times of famine was very much in vogue among learned men interested in agricultural economy or botany in the second half of the eighteenth century $(4,27)$.

In his various publications, Linné listed substitute materials that could be used for famine bread (Table 2). Some were mentioned only by name or with a short comment, while the processing and use of the most common substitutes or those regarded as best were described in greater detail.

Bark bread has been used in the subarctic area since prehistoric times (4). According to Linné, no other bread was such a common famine bread. He described how in springtime the soft inner layer can be removed from debarked pine trees, cleaned of any remaining bark, roasted or soaked to remove the resin, and dried and ground into flour. Linné had obviously eaten bark bread, since he could say that "it tastes rather well, is however more bitter than other bread". His view of bark bread was most
Table 2. Material for substitute breads, vicarii, listed by Carl von Linné in Ceres noverca arctoum (8)

\begin{tabular}{ll}
\hline Grain substitutes & \multicolumn{1}{c}{ Comments and notes } \\
\hline Stamp & \\
Chaff & \\
Mash & Zea, called slave bread in America \\
Maize & \\
Peas & \\
Beans & Papas, potato, Solanum tuberosum \\
Truffle & Tubers of spring bulb, Gagea lutea \\
Tubers & Pine bark, Pinus sylvestris \\
Bark & Roots, Calla palustris \\
Water arum & Bogbean, Menyanthes trifoliata \\
Bitter & Buds of trees; alder and hazel unsuitable \\
Buds & Flowers of red clover, Trifolium pratense \\
Clover & Seeds of corn spurrey, Spergula arvensis \\
Spurrey & Fucus saccharinus \\
Seaweed & A mixture of stamped small fish and a little flour \\
Fish & fried on a fire \\
Shoots & Pine shoots plucked in springtime \\
Flax & Unidentified flax species, Panis lini \\
Great pignut & Roots, Bunium bulbocastanum \\
\hline & \\
\hline
\end{tabular}

positive but perhaps unrealistic: "People not only sustain themselves on this, but also often become corpulent of it, indeed long for it." Linné's high regard for bark bread was shared by many of his contemporaries, but not all. For example, Pehr Adrian Gadd, the first professor of chemistry in Turku (Åbo) Academy and one of the most prominent utilitarians in Finland, condemned bark bread as "useless, if not harmful to use" (28). In Sweden, Anders Johan Retzius, a professor in Lund and an expert on the economic and pharmacological potential of Swedish flora, called bark bread "a paltry food, with which they can hardly survive and of which they always after some time get a swollen body, pale and bluish skin, big and hard stomach, constipation and finally dropsy, which ends the misery" (4).

Another grain substitute which Linné described at length was the flour made of water arum (Calla palustris) roots. The process of preparing flour from these roots was complicated. The roots were collected in the springtime, washed, dried, peeled, crushed, ground to flour, sieved and boiled with water to the consistency of thin porridge. The porridge was left in the pot for several days, and then the liquid was poured off and the resulting mass was again dried. The flour obtained could be made into dough with warm water or mixed with 
other flours. The drying and boiling were necessary to eliminate the bitter, burning taste of the roots. Linné marvelled that "such a bitter root should become such a pleasant bread, white and sweettasting", the best he had seen used in times of want in Sweden. Water arum flour was well known to the settlers in Lapland, Västerbotten and Österbotten.

The bread made of potato, which at that time was still regarded only as a substance for famine bread, Linné called truffle bread. The root of this word is the same as in the German Kartoffel. Potato bread had been recommended in Sweden by Jonas Ahlströmer as early as in the 1730s in his pioneering pamphlets on potato growing (4). Linné described the bread-making of potatoes mixed with rye flour in his Skånska Resa, published in 1751 (8), but saw potato only as a poor substitute for grain. Several other scientists, however, warmly recommended potato for bread-making. In the 1740s the Proceedings of the Swedish Royal Academy of Science had already published papers that described the successful cultivation of potato and its usefulness in the making of nourishing and tasty bread $(29,30)$. Gadd (28) thought that the best famine bread could be baked from potatoes, and Retzius (31) preferred potato and Island lichen (Cetraria islandica) to bark bread.

Of the foreign grain substitutes, Linné wrote an enthusiastic description of maize (Zea mays) bread, which he called "slave bread, the ordinary bread of slaves in America". He described the plant, its cultivation, the preparation of flour from it and the baking of small cakes by folding them in leaves and burying them in hot ash. Linné had received maize seeds, "Indian corn", from Peter Collinson, an English trader and botanist with connections to the New World (2), and had obviously experimented with their cultivation in Uppsala. He wrote, "It is fully foreign but grows easily in our gardens, gives two or three ears on each stalk, thick as arms, on all sides covered with seeds, large as peas; on every root two or three shoots often grow. Hereof one can judge its annual growth." It seems that Linné had had an opportunity to taste maize bread, since he could describe it as "very dry, heavy, tastes like pea bread".

Several other exotic examples of grain substitutes were also mentioned, but Linné did not have personal experiences of them. He commented, for example, "Fish that have been dried and baked into bread are very much used by Islanders, Hottentots and inhabitants of the Pacific coast".

Linné's investigations of substitutes for grain became of practical service when a failed harvest of the previous summer was followed by famine in 1757 (10). Linné sent a memorandum to King Adolf Fredrik in the spring of 1757 and pointed out the risk to the health of the hungry people when they ignorantly chose unsuitable plants as a substitute for grain. He included a short paper on the indigenous plants which in the shortage of grain could be used in bread-making and other cooking. His Majesty immediately permitted this leaflet to be printed at public expense and distributed throughout the country (10). Soon Linné's recipes using wild flora were read out in churches across Sweden. In Berättelse om The inhemska wäxter, som i brist af Säd kunna anwändas til Bröd- och Matredning, Linné (32) described the habitats and the popular names of about 30 edible wild plants, eight of which were recommended for bread-making.

\section{Written for the common folk}

As early as in the 1730s, Linné wrote in Diaeta Naturalis, "I have written for the common folk" (19). Actually, not much is known about the reception of his writings among common people. The language used, most often Latin, would have rendered them unavailable to the majority of Swedes. Many of Linné's students, however, achieved influential positions in academic circles and elsewhere in Swedish society, which they used to publicize widely Linnéan ideas.

The dissemination of Linnéan teachings on diet and, on particular, on bread, can be illustrated by an example from Finland. More than 20 of Linné's students came from Finland, the eastern part of the kingdom (33). Among them the greatest fame was achieved by Pehr Kalm, one of the "apostles", who Linné sent to North America to find useful plants that might tolerate the Swedish climate (2). As the first professor of economics in Turku Academy, Kalm promoted the utilitarian doctrines in Finland (34). He was particularly interested in agriculture and had even considered writing his own dissertation for Linné on economically useful plants (Plantarum indigenarum usu oeconomico) to "find which of our home plants we can use instead of bread, porridge and gruel" (35).

In this connection, however, the most interesting Finns are Johan Haartman and Carl Niclas 
Hellenius. Haartman started his studies in Turku Academy and continued in Uppsala, where he received his candidate degree in botany, tutored by Linné, in 1751, and doctorate in medicine, by Professor Rosén von Rosenstein in 1754. After his return to Turku, Haartman was nominated, recommended by Linné himself, for the newly established position of provincial medicus of south-western Finland. He founded the first academic teaching hospital in Finland, became its first physician, and from 1765, the first Finnish-born, and for a long time the only, professor of medicine in Turku Academy (36). Among the many dissertations tutored by Haartman, Fundamenta diaetetica discussed a health-preserving diet and ways of life in the Hippocratic-Galenic tradition. The most important role of Haartman's pioneering work in public enlightenment was, however, achieved by his book on the most usual illnesses and their treatments, Tydelig Underrättelse, Om de Mäst Gångbara Sjukdomars Kännande och Motande, Genom Lätta och Enfaldiga Hus-medel (37). Written in Swedish and intended for lay people, the book was greatly appreciated in both Sweden and Finland (38). It contained more than 10 pages of dietary advice. Bread and cereal foods were mentioned in much the same light as in Linné's own texts. Haartman summarized: "Bread is the most wholesome food, universally for all people, in the same way as milk".

Carl Niclas Hellenius studied medicine under Haartman and natural history as Kalm's student in Turku (39). Haartman encouraged Hellenius to continue his studies in Uppsala, where he defended his thesis in medicine in 1776 as the last doctoral student tutored by Linné. After his return to Turku, Hellenius was appointed in 1778 - also favoured by Linné's recommendation - as an associate professor of medicine and a demonstrator in botany (botanices demonstrator). In this position Hellenius gave lectures in dietetics to medical students and supervised a thesis entitled in Swedish Om finska allmogens nödbröd (Famine breads used by country folk in Finland) (40).

Linné and his followers praised bread not only as the core component of the diet, but also for its versatile role both in health and in disease. I conclude this review with the introduction of Hellenius' dissertation (40), which closely echoes the words of Carl von Linné that started this account on Linné and bread:
Of the many ways humankind has invented to make use of the rich resources of the vegetable kingdom, that of preparing wholesome and tasty bread is without doubt the most profitable. Bread contains in the smallest volume the greatest mass of the nourishing elements obtainable from plants; in all seasons and at all occasions it gives equally good and useful food; it can be stored for long periods without any loss; it heightens the taste of many of our dishes, and even more, it often changes a food which is inedible due to its kind or condition, into one which people can consume without any risk and with benefit. Therefore, it is not to be wondered if its consumption has become so common that hardly anyone, except the most savage Nations, can get along without it. Since ancient times the so-called Cerelia have been considered as the most noble plants which generous Nature has us provided.

\section{Acknowledgements}

I thank Pertti Mustajoki, MD, Bertil Roslin, PhD (Econ) and Seppo Vehkamäki, DSc (For Econ) for discussions on the economic thought and the state of medicine in eighteenth century Sweden as well as for valuable suggestions concerning rare literary sources.

\section{References}

1. Uggla AHj, Fredbärj T. Om brödet som födoämne (De pane diaetetico). Valda avhandlingar av Carl von Linné i översättning, N:r 44. Ekenes: Svenska Linné-Sällskapet; 1964.

2. Blunt W. Linnaeus. The compleat naturalist. London: Frances Lincoln; 2004.

3. Price TD. The introduction of farming in northern Europe. In: Price TD, ed. Europe's first farmers. Cambridge: Cambridge University Press; 2000. p. 260-300.

4. Campbell $\AA$. Det svenska brödet. En jämförande etnologisk-historisk undersökning [Summary: The Swedish bread]. Stockholm: Sveriges Bakeriidkareförening; 1950.

5. Soininen AM. Vanha maataloutemme. Maatalous ja maatalousväestö Suomessa perinnäisen maatalouden loppukaudella 1720-luvulta 1870-luvulle [dissertation] [Abstract: Old traditional agriculture in Finland in the eighteenth and nineteenth century]. J Sci Agric Soc Finland 1974; 46(Suppl 1): 1-459.

6. Berg G. Die Kartoffel und die Rube. Ethnol Scand 1971; 1: $158-65$.

7. Fjellström Ph. Nord- och mellansvenskt kosthåll i kulturekologisk belysning. In: Bringéus N-A. Mat och miljö. Lund: Gleerups; 1970. p. 41-64.

8. Fredbärj T. Caroli Linnaei Ceres noverca arctoum (Nordbornas styvmoderliga Ceres). Valda avhandlingar 
av Carl von Linné i översättning, N:r 45. Ekenes: Svenska Linné-Sällskapet; 1964.

9. Drake af Hagelsrum G. Linnés disputationer. En översikt. Nässjö; 1939.

10. Fredbärj T. Linné och brödet [Summary: Linnaeus and bread]. Svenska Linné-Sällskapets Årskrift 1965; 48: 16 25.

11. Lindfors AO. Linnés dietetik. Uppsala: Medicinska fakulteten i Uppsala; 1907.

12. Hvafner H. Östligt och västligt från söder till norr. In: Bringéus N-A, ed. Mat och miljö. Lund: Gleerups; 1970. p. $65-72$.

13. Heckscher EE, Montgomery A, Svensson B. Svenskt arbete och liv. Stockholm: Bonniers; 1980.

14. Lönnqvist B. Bakelser. En studie i lyxens kulturella formspråk. Helsingfors: Schildts; 1997.

15. Anon. Kajsa Wargs kokbok. Uddevalla: IBA; 1964.

16. Lindfors AO. Några Linné-studier. Uppsala: Almqvist \& Wiksell; 1907.

17. Harrison D, Ulvros EH. Historiebok för kakälskare. Lund: Historiska Media; 2003.

18. Strandell B. Läkare och medicine professorn Carl von Linné. Svenska Linné-Sällskapets Årskrift 1961; 44: 121.

19. Malmeström E. Diaeta Naturalis 1733. Innehåll och problematik [Summary: Diaeta naturalis 1733. Content and questionnability]. Svenska Linné-Sällskapets Årskrift 1965; 48: 1-4.

20. Worth-Esters J. Food as medicine. In: Kiple KF, Ornelas $\mathrm{KC}$, eds. The Cambridge world history of food. Cambridge: Cambridge University Press; 2000. p. 1534-53.

21. Hjelt OEA. Carl von Linné såsom läkare och medicinsk författare. Uppsala: Almqvist \& Wiksell; 1907.

22. Magner LN. A history of medicine, 2nd edn. London: Taylor \& Francis; 2005.

23. Sörlin S, Fagerstedt O. Linné och hans apostlar. Stockholm: Natur och Kultur; 2004.

24. Rausing L. Underwriting the economy: Linnaeus of nature and mind. History of Political Economy 2003; 35(Suppl): 173-203.

25. Guggenheim KY. Nutrition and nutritional diseases. The evolution of concepts. Lexington, MA: Collamore Press; 1981.

26. Rantatupa H. Elintarvikehuolto ja -säännöstely Suomessa vuosina 1914-1921 [dissertation] [Resumé: Approvisionnement et rationnement des vivres en Finlande dans la période 1914-1921]. Studia Historica Jyväskyläensis 17. Jyväskylä: Jyväskylän yliopisto; 1979.
27. Clark Nelson M, Svanberg I. Lichen as food. Historical perspectives on food propaganda. Svenska LinneSällskapets Årskrift 1986-87; 69: 7-51.

28. Gadd PA. Anmärkningar om nödbröd. Tidningar Utgifne Af et Sällskap i Åbo 1772; 19: 145-8.

29. Mennander CFr. Berättelse 1. Om Stampe-Bark och Misse-Bröd. Kongl Swenska Wetenskaps Academiens Handlingar 1742; 3: 284-6.

30. de la Gardie E. Försök At tilverka Bröd, Brännvin, Stärkelse och Puder af Potatos. Kongl Svenska Vetenskaps Academiens Handlingar 1748; 9: 277-8.

31. Retzius AJ. Försök til en Flora Oeconomica Sveciae eller Swenska Wäxters Nytta och Skada i Hushållningen. Vol. 1. Lund; 1806.

32. Linnaeus C. Berättelse om The inhemska wäxter som brist af Säd kunna anwändas til Bröd- och Matberening. 1757.

33. Leikola A. Linné Suomessa [Summary: Linnaeus in Finland]. Hippokrates 2006; 23: 122-38.

34. Klinge M. Professoreita. Keuruu: Otava; 1984.

35. Hulth JM. Kalm som student i Uppsala och lärjunge till Linné åren 1741-1747. Svenska Linné-Sällskapets Årskrift 1924; 7: 39-49.

36. Haltia M, Vaheri A. Johan Haartman, "Suomen lääketieteen isä". Duodecim 2006; 122: 2919-28.

37. Haartman JJ. Tydelig Underrättelse, Om de Mäst Gångbara Sjukdomars Kännande Och Motande, Genom Lätta och Enfaldiga Hus-medel; Samt et litet Res- och Hus-Apothek; Dem til tjenst, som ej hafwa tilfälle at rådfråga Läkare. Stockholm och Åbo; 1759.

38. Hjelt OEA. Johan Haartmans verksamhet vid universitetet i Åbo under åren 1754-1784 skildrad enligt hans bref. Helsingfors: Finska Litteratursällskapets tryckeri; 1911.

39. Klinge M, Leikola A. Oppi ja tiede. In: Klinge M, Knapas R, Leikola A, Strömberg J, eds. Helsingin yliopisto 1640-1990. I. Kuninkaallinen Turun Akatemia. Helsinki: Otava; 1987. p. 553-733.

40. Hellenius CN. Om finska allmogens nödbröd. Afhandling utgifven och försvarad af Johan Fredric Wallenius. Åbo; 1782.

\footnotetext{
Leena Räsänen

PO Box 66

Fl-000 I 4 University of Helsinki

Finland

Tel: +3589 |9| 5827|

Fax: +3589 191 58269

E-mail: leena.rasanen@helsinki.fi
} 